\title{
GENERAL LIABILITIES OF THE MEMBERS OF THE BOARD OF DIRECTORS IN JOINT STOCK COMPANIES UNDER THE PROVISIONS OF TURKISH COMMERCIAL LAW
}

\author{
DOI: 10.17261/Pressacademia.2020.1371
}

PAP- V.12-2020(35)-p.111-113

Seniha Dal

Marmara University, Faculty of Business Administration, Department of Commercial Law, Istanbul, Turkey. senihadal@marmara.edu.tr, ORCID: 0000-0002-3999-8395

\section{To cite this document}

Dal, S. (2020).. General liabilities of the members of the board of directors in joint stock companies under the provisions of turkish commercial law. PressAcademia Procedia (PAP), V.12, p.111-113.

Permanent link to this document: http://doi.org/10.17261/Pressacademia.2020.1371

Copyright: Published by PressAcademia and limited licensed re-use rights only.

\section{ABSTRACT}

Purpose- The purpose of this study is to include the general legal liabilities of the members of the board of directors in closed joint stock companies as regulated in the Turkish Commercial Code (TCC) Art. 553 within the scope of the study. The special liability circumstances in TCC regarding the members of the board of directors will be held out of the scope of this study. In joint stock companies, the board of directors is one of the legally mandatory bodies that must be present. The management and representation of the joint stock company is the primary duty of the board of directors. It sets forth that board members are obliged to fulfil their duties with "due care of a prudent manager". Failure to do so will result in legal liabilities for the members. General legal liabilities of the members of the board of directors are regulated in Art. 553 of TCC No. 6102. According to this provision, the legal liability of board members is based on the principle of fault. However, unlike the abolished Commercial Code, this regulation has adopted the principle of differentiated solidarity regarding the responsibility of the board members abandoning the principle of joint liability. This study covers basic acknowledgements about the principle of fault, differentiated solidarity, liability lawsuit in terms of legal liabilities of the members of the board of directors in joint stock companies. Methodology- In accordance with the principle of fault regarding the liabilities of the members of the board of directors, the fault must be proven for the members to be held legally responsible. The basis for the wrongdoing here may be the legal relationship between the board member and the joint stock company, or the unfair actions of the board members. Since the law maker has removed the presumption of negligence against the board of directors in liability lawsuits to be filed against the members of the board of directors with law No. 6335 , the proof of the fault is determined according to the general provisions. The kind of fault that should be existent in the members is objective fault, not subjective fault. According to the principle of objective fault, a board member is obliged to adopt the consideration and care shown by a conscious, sensible and reasonable person in the same social environment. In the presence of these traits and circumstances, members do not bear liability since no kind of faulty act can be attributed. TCC No. 6102 Art. 557 has brought a significant change to the members of the board of directors. With this change, in terms of fault liability instead of joint liability, differentiated solidarity concept has been adopted. Differentiated solidarity means that if more than one party is obliged to indemnify the same damage, each is held liable to the extent that the damage can be charged to each party based on its wilful misconduct and on a case-by-case basis.In order to be able to speak of joint liability principle, to begin with, more than one person should be held responsible for the damage. When the incurred damage is caused by more than one person, there is joint liability among the actors. This solace is against the harmed. In other words, each member of the board of directors who contributes to the birth of the damage is liable to the injured person for all of the damage, regardless of the degree of their fault. The principle of joint liability is valid not in the internal relationship between the members of the board of directors, but in the external relationship in which they are liable to the harmed. This understanding protects the injured party. Therefore, the member who gave the damage is responsible for compensating the loss of the injured, even if the extent of their intervention is minor. Differentiated solidarity principle, on the other hand, states that where more than one person shall be responsible for the damage incurred, rather than being held responsible for the overall damage, each and every board member may be found liable pro rata to the degree of their fault and status of the situation. The differentiated solidarity principle allows the members of the board of directors who are jointly and severally liable to use their personal reasons for extenuation against the injured who suffers in the external relationship. It should be noted that, as in the principle of joint liability, in this principle as well, more than one board member must be involved in the occurrence of the damage. For, none of these principles can be applied in terms of liability for a damage caused by the fault of a single board member. For this reason, it is not possible to apply the differentiated solidarity principle to joint stock companies managed by a single member board of directors. In summary, in accordance with the differentiated solidarity principle, each negligent board member taking part in the incurred damage will be obliged to compensate for the amount of the damage that may be attributed to them, not for the total, but in proportion to the degree of their personal faults and requirements of the situation. The differentiated solidarity principle allows the members to claim personal explanation /discount situations which used to be impossible to state when joint liability principle was in order and could only be claimed against other board members in the internal circle but could not be claimed against the injured party who happens to belong to the external circle. 
Findings- In accordance with TCC Art. 553, members of the board of directors shall be held legally liable for the damage they cause to the company, shareholders and company creditors in case they fail to fulfill their obligations arising from the law and articles of association at the extent of their fault. To file a liability lawsuit, the members must act in defiance of the articles of association and the regulations regarding and these acts must lead to a loss of the company. Art. 555 of TCC states that the company and the shareholders have the right to file a suit due to the loses of the joint stock company. Pursuant to the aforementioned provision, the provisions of Art. 553 set forth that members of the board of directors are obliged to pay the losses of the company resulting from their faults to the joint stock company. However, the shareholders are also granted with the right to file a lawsuit against the members of the board of directors in case the members of the board of directors may not be willing file a lawsuit against themselves, mainly because they have the authority to represent the company. In other words, in case of an incurred loss owing to the members of the board of directors, shareholders who suffer the loss has the right to sue independently like the company itself. If the joint stock company suffers a damage, the compensation is paid to the company as a result of the lawsuit that is filed. The compensation claims against the liable members of the board of directors must be made within two years from the date on which the claimant became aware of the loss and the person that is responsible of it, in any case, the right to claim expires in five years from the day of the occurrence of the act that caused the damage. Art. 556 of TCC specifies that it is possible for the creditors of the company to file a liability lawsuit against the members of the board of directors only if the company goes bankrupt. Nevertheless, even then, the priority right to sue is given to the bankruptcy administration. If the bankruptcy administration does not file a lawsuit, the company creditor may file one on the condition that the compensation will be paid to the company. The parties that hold passive capacity to sue in terms of liability cases are specified separately in Art. 553. Accordingly, founders, members of the board of directors, executives and liquidators are liable for the damages they cause to the company. However, taking into consideration the focus of the study, only the members of the board of directors are referred here.

Conclusion- Unlike the former Commercial Code, TCC numbered 6102 has brought novel changes to the regulations regarding the general liability conditions of members of board of directors in Art. 553. No member without a fault shall be held responsible based on Art. 553. As a result of the amendment made by the law No. 6335, thanks to removal of the principle of the presumption of negligence, the members of the board of directors are relieved of the burden of proving their innocence. In addition, introducing the principle of differentiated solidarity with the Art. 557 an understanding that holds each member of the board of directors responsible only in proportion to their faults in the external relations has been adopted. With this regulation, no member will be held liable for any kind of loss and corruption beyond their control.

Keywords: Joint stock company, board of directors, liability, fault, differentiated solidarity

JEL Kodları: K22

\section{TÜRK TICARET KANUNU HÜKÜMLERINE GÖRE ANONIM ŞIRKETLERDE YÖNETIM KURULU ÜYELERININ GENEL HUKUKI SORUMLULUĞU}

\section{ÖZET}

Amaç- Bu çalışmanın amacı, halka kapalı anonim şirketlerde yönetim kurulu üyelerinin Türk Ticaret Kanunu (TTK) M. 553'de düzenlenen genel hukuki sorumluluğuna çalışmanın elverdiği ölçüde yer vermektir. Çalışmada yönetim kurulu üyeleri için TTK'da düzenlenmiş özel sorumluluk hallerine yer verilmeyecektir. Anonim şirketlerde yönetim kurulu kanunen bulunması gereken zorunlu organlardan biridir. Anonim şirketin yönetim ve temsili yönetim kurulunun asli görevidir. Yönetim kurulu üyeleri görevlerini ifa ederken "tedbirli bir yöneticinin özeniyle" hareket etmeleri gerekmektedir. Buna aksi davranış yönetim kurulu üyelerinin hukuki sorumluluğuna neden olacaktır. 6102 sayılı TTK m. 553 'de yönetim kurulu üyelerinin genel hukuki sorumluluğu düzenlenmiştir. Anılan hüküm uyarınca, yönetim kurulu üyelerinin hukuki sorumluluğu kusur prensibine dayandırmıştır. Bununla birlikte mülga Ticaret Kanunundan farklı olarak bu düzenleme yönetim kurulu üyelerinin sorumluluğunda mutlak teselsül ilkesini terk etmiş yerine farklılaştırılmış teselsül ilkesini benimsemiştir. Bu çalışmada anonim şirketlerde yönetim kurulu üyelerinin hukuki sorumluluğunda kusur prensibi, farklılaştırılmış teselsül ilkesi ve sorumluluk davasına ilişkin temel bilgiler ele alınacaktır.

Yöntem- Yönetim kurulu üyelerinin sorumluluğunda kusur ilkesi gereğince yönetim kurulu üyelerinin hukuki sorumluluklarının doğabilmesi için kusurun ispat edilmesi gerekmektedir. Buradaki kusurun dayanağı yönetim kurulu üyesi ile anonim şirket arasındaki hukuki ilişki olabileceği gibi yönetim kurulu üyelerinin haksız eylemleri de olabilecektir. Kanun koyucu, 6335 sayılı Kanun ile yönetim kurulu üyelerine karşı açılacak sorumluluk davalarında yönetim kurulu aleyhine olan kusur karinesini kaldırdığından kusurun ispatı genel hükümlere göre belirlenmektedir. Yönetim kurulu üyelerinde aranan kusur sübjektif kusur değil objektif kusurdur. Objektif kusur ilkesine göre, bir yönetim kurulu üyesi aynı sosyal çevrede bulunan bilinçli, makul ve mantıklı bir kişinin göstermesi gereken dikkat ve özeni göstermekle yükümlüdür. Bir diğer ifadeyle, yönetim kurulu üyeleri hukuki sorumluluğuna sebep olacak eylem ve işlemlerinde aynı sosyal çevrede bulunan bilinçli, makul ve mantıklı bir kişinin göstermesi gereken dikkat ve özeni göstermiş ise tedbirli bir yönetici gibi davranmış olacaktır. Bu hallerin varlığında yönetim kurulu üyelerine kusurlu bir eylemin isnadı mümkün olmayacağından hukuki sorumlulukları da doğmayacaktır. 6102 sayılı TTK m. 557'deki düzenlemesi ile yönetim kurulu üyelerinin sorumluluğunda önemli bir değişikliğe gitmiştir. Bu değişiklik ile kusur sorumluluğunda mutlak teselsül ilkesi terk edilerek yerine farklılaştırılmış teselsül ilkesi benimsenmiştir. Farklılaştırılmış teselsül anlam olarak birden fazla tarafın tazmin etmek zorunda olduğu bir zararda tarafların her biri somut olayın özelliğine göre kendilerine yüklenebileceği ölçüde zarardan sorumlu tutulmasıdır. Mutlak teselsül ilkesinden söz edebilmek için her şeyden önce zararın meydana gelmesi durumunda bu zarardan birden fazla kişinin sorumlu tutulabiliyor olması gerekir. Birden fazla kişinin birlikte meydana getirdikleri zarardan dolayı aralarında tam bir teselsül vardır. Bu teselsül zarar görene karşı söz konusudur. Yani zararın doğumuna katkısı bulunan her bir yönetim kurulu üyesi kendi kusurlarının derecesinden bağımsız olarak zararın tamamından zarar görene karşı sorumludurlar. Mutlak teselsül ilkesi yönetim kurulu üyeleri arasındaki iç ilişkide değil zarar görene karşı sorumlu oldukları dış ilişkide geçerlidir. Bu anlayış zarar gören alacaklının korunduğu bir 
anlayıştır. Bunun sonucunda da zarar veren yönetim kurulu üyesi zararın oluşumuna katkısı çok büyük oranda olmasa bile zarar görene karşı zararın tamamını tazmin etmekle yükümlü olmaktadır. İşte farklılaştırımış teselsül ilkesinde yönetim kurulu üyelerinin her biri zararın tamamından sorumlu olmak yerine zarardan, kusuruna ve durumun gereklerine göre kendisine yükletilebildiği ölçüde diğer üyelerle birlikte sorumlu olmaktadır. Farklılaştırılmış teselsül ilkesi, müteselsil borçlu olan yönetim kurulu üyelerinin şahsi indirim sebeplerini, dış ilişkide zarar gören alacaklıya karşı kullanabilmelerine izin vermektedir.

Belirtmek gerekir ki, mutlak teselsül ilkesinde olduğu gibi bu ilkede de zararın meydana gelmesinde birden fazla yönetim kurulu üyesinin kusuru bulunmalıdır. Zira, hem mutlak teselsül ilkesi hem de farklılaştırılmış teselsül ilkesi tek bir yönetim kurulu üyesinin kusuru ile verdiği zarardan kaynaklanan sorumlulukta uygulanamaz. Bu nedenle tek kişilik yönetim kurulu ile yönetilen anonim şirketlerde farklılaştırılmış teselsül ilkesinin uygulanması mümkün değildir. Özetle, farklılaştırılmış teselsül ilkesi gereğince meydana gelen zararda kusurları bulunan her bir yönetim kurulu üyeleri zararın tamamından değil kişisel kusurlarının derecesi oranında ve durumun gereklerine göre kendilerine yükletilebilecek zarar miktarını tazminat olarak ödemekle yükümlü olacaklardır. Farklılaştırılmış teselsül ilkesi gereğince mutlak teselsül ilkesi gereğince sadece iç ilişkide diğer yönetim kurulu üyelerine karşı ileri sürülebilen ancak dış ilişkide zarar gören alacaklıya karşı ileri süremedikleri şahsi indirim durumlarını dış ilişkide alacaklıya karşıda ileri sürebilmektedirler.

Bulgular- Yönetim Kurulu üyeleri, TTK m. 553 uyarınca kanundan veya esas sözleşmeden doğan yükümlülüklerini kusurlarıyla ihlal ettikleri takdirde hem şirkete hem pay sahiplerine hem de şirket alacaklılarına karşı verdikleri zarardan kusurları oranında hukuken sorumlu tutulmuşlardır. Sorumluluk davasının açılabilmesi için şirket yönetim kurulu üyelerinin esas sözleşmeye ve kanuna kusurlu olarak aykırı davranmış ve bu davranışından dolayı da şirketin zarar görmüş olması gerekmektedir. TTK m. 555'e göre anonim şirketin zararı nedeniyle şirket ve ortaklar aktif dava ehliyetine sahiptirler. Anılan hüküm uyarınca, yönetim kurulu üyeleri kusurları sebebiyle şirketin uğradığı zararı m. 553 hükümlerine göre anonim şirkete ödemekle yükümlüdür. Ancak, yönetim kurulu üyelerinin esasen şirketi temsil yetkisine sahip olmaları sebebiyle kendi aleyhlerine dava açmamaları ihtimaline karşılık pay sahiplerine de yönetim kurulu üyelerine karşı dava açma hakkı verilmiştir. Bir başka deyişle, yönetim kurulu üyelerinin şirketi zarara uğratması halinde, şirket bu davayı açabileceği gibi zarara uğrayan pay sahipleri de bağımsız olarak bu davayı açabileceklerdir. Anonim şirketin zarara uğraması halinde açılan davada tazminat şirkete ödenir. Hukuki sorumluluğu bulunan yönetim kurulu üyelerine karşı tazminat isteme hakkı davacının zararı ve sorumluyu öğrendiği tarihten itibaren iki yıl ve her halde zararı doğuran fiilin meydana geldiği günden itibaren beş yıl geçmekle zamanaşımına uğrar. TTK m. 556 uyarınca şirket alacaklılarının yönetim kurulu üyelerine karşı sorumluluk davasını açabilmeleri anonim şirketin iflası halinde mümkündür. Bu halde dahi öncelikli dava açma hakkı iflas idaresinindir. Şirket alacaklısı sorumluluk davasını ancak iflas idaresinin davayı açmaması halinde tazminat şirkete verilmek üzere açabilecektir. Sorumluluk davasında pasif dava ehliyetine sahip olanlar m. 553'de sayma yöntemine göre belirlenmiştir. Buna göre, kurucuların, yönetim kurulu üyelerinin, yöneticilerin ve tasfiye memurlarının şirkete verdikleri zarardan sorumlulukları bulunmaktadır. Ancak çalışmanın konusu gereğince burada sadece yönetim kurulu üyeleri işaret edilmiştir.

Sonuç- 6102 sayılı TTK yönetim kurulu üyelerinin genel hukuki sorumluluğunu m. 553'de mülga Ticaret Kanunundan farklı olarak özel olarak düzenlemiştir. Yönetim kurulu üyelerinin hukuki sorumluluğunun dayanağı kusur prensibidir. Yani, kusuru bulunmayan hiçbir yönetim kurulu üyesi m. 553'e dayanarak sorumlu tutulamayacaktır. 6335 Sayılı Kanun ile yapılan düzenleme sonucunda kusurun ispatında yönetim kurulu aleyhine olan kusur karinesi ilkesinden vazgeçilerek yönetim kurulu üyeleri, kusursuzluğunu ispat etme külfetinden kurtulmuşlardır. Ayrıca m. 557 ile farklılaştırılmış teselsül ilkesi kabul edilerek her yönetim kurulu üyesini dış ilişkide sadece kusurları oranında sorumlu tutan anlayış getirilmiştir. Bu düzenleme sonucunda hiçbir yönetim kurulu üyesi kontrolü dışında kalan zararlardan sorumlu tutulamayacaktır.

Anahtar Kelimeler: Anonim şirket, yönetim kurulu üyeleri, hukuki sorumluluk, kusur, farklılaştırılmış teselsül ilkesi JEL Kodları: K22

\section{KAYNAKÇA}

Akdağ Güney, N. (2016). Anonim Şirket Yönetim Kurulu, Vedat Kitapçılık, İstanbul 2016.

Can, M. Ç. (2017). "Pay Sahiplerinin Veya Alacaklıların Doğrudan Zararlarının Tazmini Amacıyla İkame Edilen Sorumluluk Davalarında TTK m. 1534'ün Etkisi”, Gazi Üniversitesi Hukuk Fakültesi Dergisi C. XXI, Y. 2017, Sa.4.

Dinç, S. (2018). Anonim Şirketlerde Yönetim Kurulu Üyelerinin Hukuki Sorumluluğu, Ankara 2018.

Doğan, F. (2011). Anonim Şirket Yönetim Kurulunun Organizasyonu ve Yönetim Yetkisinin Devri, Vedat Kitapçılık, İstanbul 2011.

Eriş, G. (2012). Ticari İşletme ve Şirketler, Seçkin Yayınları, Ankara 2012.

Ömür, R.C. (2020). Anonim Şirketlerde Yönetim Kurulu, Adalet Yayınevi, Ankara 2020.

Sumer, A. (2020). Ticaret Hukuku Ders Kitabı, Beta Basım Yayım Dağıtım, İstanbul 2020.

6102 Sayılı "Türk Ticaret Kanunu”, 14.11.2011 tarih ve 27846 sayılı Resmi Gazete.

6335 Sayılı "Türk Ticaret Kanunu İle Türk Ticaret Kanununun Yürürlüğü ve Uygulama Şekli Hakkında Kanunda Değişiklik”, 30.06 .2012 tarih ve 28339 sayılı Resmi Gazete.

TTK m. 553 gerekçe: http://www.ticaretkanunu.net/konu/ttk-553/

TTK m. 557 gerekçe: http://www.ticaretkanunu.net/ttk-madde-557/ 